\title{
ONLINE-BASED QUIZ MAKING TRAINING FOR MATHEMATICS TEACHERS OF SMA NEGERI 3 PADANG DURING THE PANDEMIC
}

\section{PELATIHAN PEMBUATAN KUIS ONLINE BAGI GURU-GURU MATEMATIKA SMA NEGERI 3 PADANG DI MASA PANDEMI}

\author{
Ainil Mardiyah ${ }^{1}$, Hafizah Delyana ${ }^{2}$, Lita Lovia ${ }^{3}$, Ali Asmar ${ }^{4}$ \\ ${ }^{1,2,3}$ STKIP PGRI Sumatera Barat \\ ${ }^{4}$ Universitas Negeri Padang \\ *E-mail:m.ainil@yahoo.com, hafizahdelyana@gmail.com, Lita_lovia@yahoo.com, \\ aliasmar.sumbar@gmail.com
}

\begin{abstract}
The world of education is currently experiencing a very extraordinary event. The Covid-19 pandemic has a very broad impact on participants and educational institutions. Our education system must be ready to take the leap to transform online learning for all students and by all teachers. We are entering a new era to build creativity, hone student skills, and improve our quality with changes in systems, perspectives and patterns of our interactions with technology. Every individual who is in an educational environment must be able to use technology that can help the learning process, especially in schools. Likewise, with the implementation of teaching and learning at SMAN 3 Padang, the process of implementing learning in these schools currently cannot be carried out face-to-face in class as usual. Students take lessons from home. To find out the ability of teacher students, they must evaluate the learning that has been given. One of them is by giving the teacher online quizzes because face to face is no longer possible during the Covid 19 pandemic. Mathematics is one of the subjects considered difficult by students, especially for mastery of Olympic questions. For this reason, teachers are required to have creativity so that learning can be understood by students. Mathematics teachers are given training that supports this. The training that will be provided is in the form of making questions for quizzes which are carried out online. The students will solve these questions in accordance with the specified time. Teachers who take part in the training are expected to be able to motivate and evaluate students' ability to work on Olympic questions even though they are carried out online.
\end{abstract}

Keywords: Teacher, Quiz, Online, Pandemic, Training.

\begin{abstract}
ABSTRAK
Dunia pendidikan saat ini sedang mengalami kejadian yang sangat luar biasa. Pandemi Covid-19 berpengaruh sangat luas bagi para peserta dan institusi pendidikan. Sistem pendidikan kita harus siap melakukan lompatan untuk melakukan transformasi pembelajaran daring bagi semua siswa dan oleh semua guru. Kita memasuki era baru untuk membangun kreatifitas, mengasah skill siswa, dan peningkatan kualitas diri dengan perubahan sistem, cara pandang dan pola interaksi kita dengan teknologi. Setiap individu yang berada dalam lingkungan pendidikan harus mampu menggunakan teknologi yang bisa membantu proses pembelajaran terutama di sekolah. Demikian juga hal nya dengan pelaksanaan belajar mengajar di SMAN 3 Padang, proses pelaksanaan pembelajaran di sekolah tersebut saat ini tidak dapat dilaksanakan tatap muka secara langsung di kelas seperti biasa. Siswa-siswa mengikuti pembelajaran dari rumah. Untuk mengetahui kemampuan siswa guruguru harus melakukan evaluasi terhadap pembelajaran yang sudah diberikan. Salah satunya dengan cara guru memberikan kuis secara online karena tatap muka sudah tidak memungkinkan selama masa
\end{abstract}




\section{Rangkiang: Lurnal Pengabdian Pada Masyarakat UPSM STKIP PER/ Sumatera Barat}

ISSN: (2721-2688) Vol. 2 No 2 (Desember 2020): 124 - 130

pandemi covid 19 masih terjadi. Matematika merupakan salah satu mata pelajaran yang dianggap sulit oleh siswa, apalagi untuk penguasaan soal-soal olimpiade. Untuk itu guru dituntut memiliki kreatifitas sehingga pembelajaran dapat dipahami oleh siswa. Guru-guru matematika diberikan pelatihan yang mendukung hal tersebut. Pelatihan yang akan diberikan berupa pembuatan soal-soal untuk kuis yang dilakukan secara online. Soal-soal tersebut akan diselesaikan oleh siswa sesuai dengan waktu yang sudah ditentukan. Guru-guru yang mengikuti pelatihan diharapkan dapat memotivasi dan mengevaluasi kemampuan siswa untuk mengerjakan soal-soal olimpiade meski dilaksanakan secara online.

Kata kunci: Guru, Kuis, Online, Pandemi, Pelatihan.

\section{PENDAHULUAN}

Perkembangan teknologi informasi dan komunikasi di era Industri 4.0 telah memiliki pengaruh yang besar terhadap proses pengajaran dan pembelajaran. Kemudahan akses teknologi telah digunakan oleh para pengajar untuk meningkatkan kualitas pendidikan (Khusniyah \& Hakim, 2019). Dunia pendidikan saat ini sedang mengalami kejadian yang sangat luar biasa. Pandemi Covid-19 berpengaruh sangat luas bagi para peserta dan institusi pendidikan. Ujian Nasional ditiadakan, dan konsep "belajar dari rumah" digaungkan, dan pada akhirnya memaksa para pelaku pendidikan untuk menerapkan pembelajaran dalam jaringan (daring). Sistem pendidikan kita harus siap melakukan lompatan untuk melakukan transformasi pembelajaran daring bagi semua siswa dan oleh semua guru. Kita memasuki era baru untuk membangun kreatifitas, mengasah skill siswa, dan peningkatan kualitas diri dengan perubahan sistem, cara pandang dan pola interaksi kita dengan teknologi.

Pemerintah melalui Kementrian Pendidikan dan Kebudayaan, telah mengeluarkan Surat Edaran No. 4 tentang Pelaksanaan Kebijakan Pendidikan dalam Masa Darurat Penyebaran Corona Virus Disease (Covid-19) terhitung mula 24 Maret 2020. Adanya surat tersebut, menyebabkan semua instansi pendidikan mengambil langkah cepat sebagai respon antisipasi penyebaran Covid-19 dan keterlaksanaan pembelajaran. Proses pelaksanaan pembelajaran di SMA Negeri 3 Padang saat ini tidak dapat dilaksanakan tatap muka secara langsung di kelas seperti biasa. Siswa-siswa mengikuti pembelajaran dari rumah. Sekolah harus membiasakan guru-guru dan siswa untuk mengikuti proses pembelajaran daring. Selama proses pembelajaran daring siswa-siswa tetap di evaluasi untuk mengetahui sejauh mana pengetahuan dikuasai oleh siswa.

Menurut (Malyana, 2020) Masa Covid-19 menuntut guru sebagai tenaga pendidik, tetap dituntut menjalakan pendidikan di sekolah. Pembelajaran diharuskan tetap berlangsung agar pendidikan terjamin. Tugas pokok dan fungsi guru yang melekat tetap akan dilaksanakan, karena guru diharapkan menjalankan pendidikan dan pembelajarannya, maka guru dituntut kreativitasnya sebagai fasilitator dalam pembelajaran. Guru-guru matematika di sekolah tersebut belum bisa menggunakan aplikasi untuk membuat kuis secara online, sementara kemampuan matematika siswa tetap harus dilatih dan ditingkatkan. Untuk melakukan evaluasi kemampuan siswa diperlukan suatu aplikasi online yang harus dipahami oleh guru. Tidak semua aplikasi yang ada sesuai dengan kebutuhan pembelajaran, akan tetapi guru-guru bisa memilih aplikasi yang cocok dengan mata pelajaran tersebut. Untuk itu guruguru matematika di SMAN 3 Padang khususnya harus dibekali dengan pengetahuan tentang penggunaan aplikasi terutama dalam penyelesaian soal-soal olimpiade matematika dalam bentuk kuis.

Pembelajaran daring memiliki banyak keunggulan. Oleh karena itu, seharusnya pembelajaran daring tidak sekedar menjadi pengganti dari pembelajaran konvensional (tatap 


\section{Rangkiang: Lurnal Pengabdian Pada Masyarakat UPSM STKIP PER/ Sumatera Barat}

ISSN: (2721-2688) Vol. 2 No 2 (Desember 2020): 124 - 130

muka), tetapi kelak bisa berjalan beriringan, berkelanjutan, dengan pembelajaran konvensional (Rigianti, 2020). Momentum penanggulangan Covid-19 saat ini adalah saat yang tepat bagi pemerintah, yayasan, dan berbagai institusi pendidikan meningkatkan kemampuan agar pembelajaran daring bisa berkelanjutan, dan tidak kemudian berhenti atau ditiadakan setelah pandemi Covid-19 berakhir. Kunci efektivitas dari sistem pembelajaran daring adalah bagaimana seorang guru tetap kreatif untuk menyajikan pembelajaran daring secara menyenangkan dan mudah dimengerti sehingga para siswa tidak merasa bosan dan tetap produktif di rumah (Handarini, 2020). Guru dituntut untuk inovatif dalam menggunakan pembelajaran dengan model daring (Anugrahana, 2020).

Pembelajaran online menghubungkan pembelajar (peserta didik) dengan sumber belajarnya (database, pakar/instruktur, perpustakaan) yang secara fisik terpisah atau bahkan berjauhan namun dapat saling berkomunikasi, berinteraksi atau berkolaborasi (secara langsung/synchronous dan secara tidak langsung/asynchronous)(Rosali et al., 2020). Pemberian kuis secara online adalah salah satu bentuk pembelajaran daring. Pemberian kuis merupakan salah satu cara untuk melatih siswa melakukan refleksi terhadap materi yang baru diajarkan sekaligus mengevaluasi penguasaan materi, sehingga membantu siswa membangun kemampuan melakukan asesmen diri atas tingkat pemahaman yang dicapai. Untuk melaksanakan kuis secara online dibutuhkan sebuah media atau aplikasi.

Salah satu nya adalah media kahoot. Dengan menggunakan Kahoot, Guru bisa mengetes pemahaman siswa melalui kuis yang sangat menyenangkan. Teknologi pembelajaran jarak jauh yang satu ini memang sangat disarankan digunakan, karena bisa menjadi salah satu cara untuk membuat belajar tidak membosankan. Selain itu, Kahoot juga cocok digunakan dalam masa belajar di rumah.

Aplikasi kahoot juga dapat digunakan sebagai media untuk pembelajaran matematika. Guru dapat memberikan soal kepada siswa dan diselesaikan oleh siswa pada waktu yang sesuai dengan yang sudah ditetapkan. Menurut (Putria et al., 2020) beberapa kelebihan dari pembelajaran daring yaitu adanya keluwesan waktu dan tempat belajar, misalnya belajar dapat dilakukan si kamar, ruang tamu dan sebagainya serta waktu yang diseseuaikan misalnya pagi, siang, sore atau malam. Dapat mengatasi permasalahan mengenai jarak, misalnya peserta didik tidak harus pergi ke sekolah dahulu untuk belajar. Tidak ada batasan dan dapat mencakup area yang luas. Sehingga guru bisa mengevaluasi kemampuan siswa dengan materi yang sudah diberikan. Termasuk melatih siswa-siswa untuk mempersiapkan diri dalam kompetisi atau kegiatan olimpiade yang diadakan oleh pemerintah maupun pihak lainnya.

\section{METODE}

Berdasarkan masalah mitra, maka solusi yang ditawarkan adalah dengan mengadakan pelatihan pembuatan Kuis Online. Pelatihan diadakan selama 3 kali pertemuan dalam jangka waktu 1 minggu. Pelatihan ini dilaksanakan dengan metode bimbingan melalui diktat. Hal ini bertujuan untuk melatih guru mampu membuat kuis pembelajaran yang berbasis IT menggunakan aplikasi Kahoot. Langkah-langkah pelaksanaan kegiatan pengabdian ini adalah sebagai berikut:

1. Tahap Persiapan: Merancang modul pelatihan, Mempersiapkan peralatan penunjang kegiatan, Mengurus administrasi seperti perizinan melakukan kegiatan baik dari PT maupun dari sekolah mitra, Memberikan pelatihan kepada mahasiswa yang terlibat pada kegiatan pelatihan, Menyepakati jadwal pelaksanaan kegiatan pelatihan dengan kedua mitra 


\section{Rangkiang: Lurna/ Pengabdian Pada Masyarakat \\ UPSM STKIP PGR/ Sumatera Barat}

ISSN: (2721-2688) Vol. 2 No 2 (Desember 2020): 124 - 130

2. Tahap Pelaksanaan: Melaksanakan kegiatan pelatihan sebanyak 3 kali pertemuan pada guru-guru matematika di SMA Negeri 3 Padang.

3. Tahap Akhir: Pembuatan laporan Jika guru sudah mampu memahami cara membuat kuis pembelajaran berbasis IT, maka diharapkan guru mampu mengaplikasikannya dalam proses pembelajaran. Penggunaan media ini akan meningkatkan pemahaman konsep siswa terhadap materi pembelajaran.

Sebelum pelatihan dilaksanakan terlebih dahulu tim dosen membuat soal olimpiade berbasis kemampuan Pemecahan Masalah yang digunakan sebagai bahan dalam mengikuti proses pelatihan. Sekolah mitra menyediakan labor komputer setiap pertemuan dan mengikutsertakan 7 orang guru matematika.

\section{HASIL DAN PEMBAHASAN}

Pembelajaran online merupakan inovasi pendidikan untuk menjawab tantangan akan ketersediaan sumber belajar yang variatif. Keberhasilan dari suatu model ataupun media pembelajaran tergantung dari karakteristik peserta didiknya (Dewi, 2020). Kegiatan pengabdian ini berlangsung sebanyak tiga kali pertemuan. Pada pertemuan pertama kegiatan yang dilakukan yaitu pengenalan aplikasi Kahoot dalam pembuatan kuis online. Selanjutnya pada pertemuan kedua, kegiatan yang dilakukan yaitu penyajian materi tentang soal-soal olimpiade yang mengasah keterampilan kemampuan pemecahan masalah matematis. Pada pertemuan terakhir guru melakukan latihan pembuatan kuis online menggunakan aplikasi Kahoot tentang soal-soal olimpiade. Kebutuhan koneksi internet dalam penggunaan aplikasi ini menjadi hal yang sangat penting dalam pelaksanaan pembelajaran daring (Rigianti, 2020).

Beberapa peralatan harus dipersiapkan sebelum proses evaluasi pembelajaran dilakukan dengan menggunakan Kahoot agar memperoleh interaksi evaluasi optimal yaitu:

a. Peralatan yang harus dipersiapkan oleh guru adalah Overhead Projector dan Layar

b. Guru juga membawa Smartphone, tablet atau Laptop

c. Sekolah menyiapkan koneksi internet kuat dan reliabel. Melalui prasyarat perlengkapan diatas telah terpenuhi, maka dapat dilakukan proses berikutnya merupakan tahapan pembuatan quiz pada kahoot. Berikut tampilan awal mulai mendaftar Kahoot.

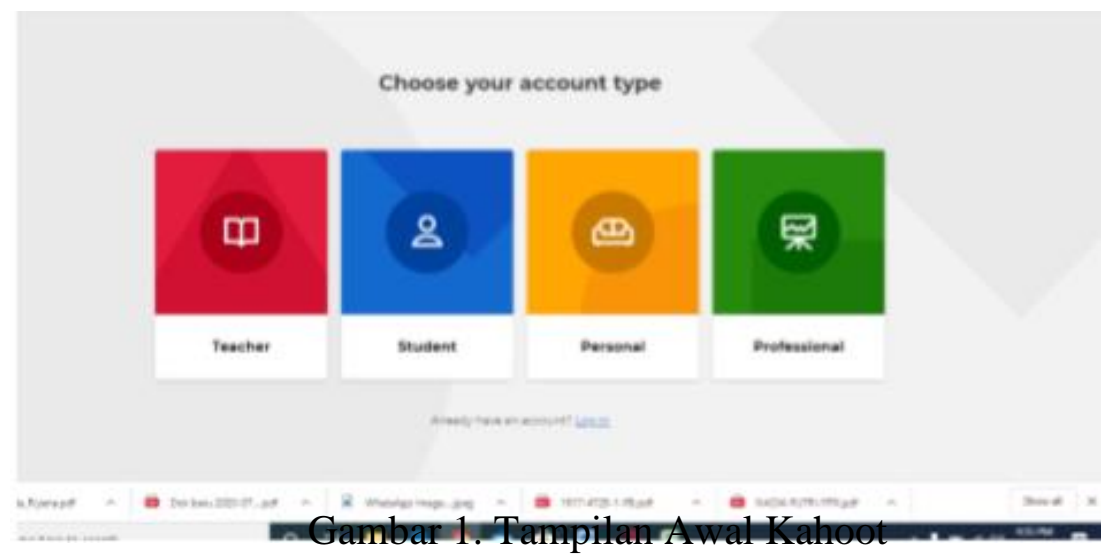

Pada Gambar 1, seorang guru akan memilih/ mengklik "teacher". Sedangkan siswa mengklik "student". Pada tahapan ini ada dua metode untuk membuat kegiatan evaluasi yaitu menggunakan komputer dan smartphone. Jika menggunakan komputer, tahapan dapat dilakukan sesuai langkah-langkah berikut ini: 
a. Ketik kahoot.com dan log in menggunakan akun kahoot, jika belum silahkan mendaftar melalui tombol sign up for free dan mendaftar dengan menggunakan akun gmail atau facebook. b. Buka kahoot sesuai dengan yang diinginkan, click quiz untuk membuat pertanyaan tipe multiple choice. c. Setiap pertanyaan dapat di setting lamanya waktu untuk menjawab dan besar skor yang didapat bergantung tingkat kesulitan pada soal. d. Tahap akhir, setiap soal di kahoot dapat di tambahkan gambar dan video untuk menambah kontek yang menarik atau memberikan bantuan untuk menjawab soal. e. Jika sudah selesai, copy link atau dapatkan PIN (kombinasi angka) untuk mengkases quiz yang telah dibuat. Untuk para peserta didik, tidak perlu mendaftar akun seperti ketika masuk sebagai guru. Hanya membutuhkan PIN atau LINK yang telah didapatkan dari akun guru ketika membuat quiz.

Untuk memainkan kahoot ini hanya tiga tahap:

a. Jalankan kahoot dari akun sebagai guru dan tampilkan pada layar, kemudian klik play dan pilih mode antara klasik (perorangan $=1$ alat untuk 1 orang) atau mode tim ( 1 alat untuk beberapa orang). Tunggu hingga muncul pin seperti pada gambar 2 berikut ini.

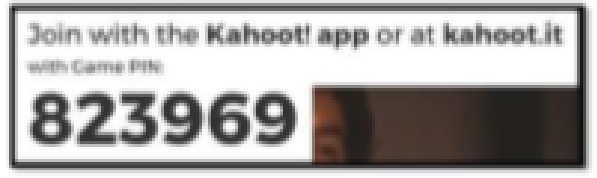

Gambar 2. Tampilan pin Kahoot

b. Peserta didik dapat mengakses langsung kahoot.it dan join dengan menggunakan PIN yang muncul. Peserta didik diharapkan menyiapkan nama panggilan atau nama tim jika digunakan pada mode grup.

c. Tunggu hingga muncul nama peserta didik di monitor utama guru. Kemudian klik mulai.

Selama kegiatan PPM ini, para guru tampak terlihat sangat antusias dan interaktif. Berdasarkan hasil wawancara tim PPM diperoleh informasi bahwa para guru memiliki ketertarikan untuk dapat memperoleh pelatihan lanjutan dari kegiatan yang telah dilakukan saat ini. Sehingga mereka dapat mengaplikasikan Kahoot ini pada bentuk soal-soal dengan tipe yang lain. Banyak pertanyaan muncul terutama pada saat praktek penggunaan Kahoot. Hasil pengamatan menunjukkan bahwa beberapa guru masih mengalami kesulitan dalam mengoperasikan Kahoot. Sebagian guru telah mengenal aplikasi ini sedangkan sisanya baru mengenal Kahoot, sehingga mereka masih terlihat kesulitan dalam pengoperasian aplikai ini tanpa didampingi ataupun tanpa melihat petunjuk yang ada pada modul. Sehingga memakan waktu yang cukup lama untuk dapat mengerjakan satu soal. Selain itu, Kendala yang sering kali muncul dalam kegiatan ini adalah bahwa para guru terkadang menanyakan sesuatu hal atau materi yang sulit diimplementasikan dengan Kahoot. Sehingga dibutuhkan penjelasan yang jelas dari tim untuk dapat memberikan arahan sehingga tidak terjadi kekeliruan dalam penggunaan Kahoot di pembelajaran matematika. 


\section{Rangkiang: Lurnal Pengabdian Pada Masyarakat UPSM STKIP PGR/ Sumatera Barat}

ISSN: (2721-2688) Vol. 2 No 2 (Desember 2020): 124 - 130

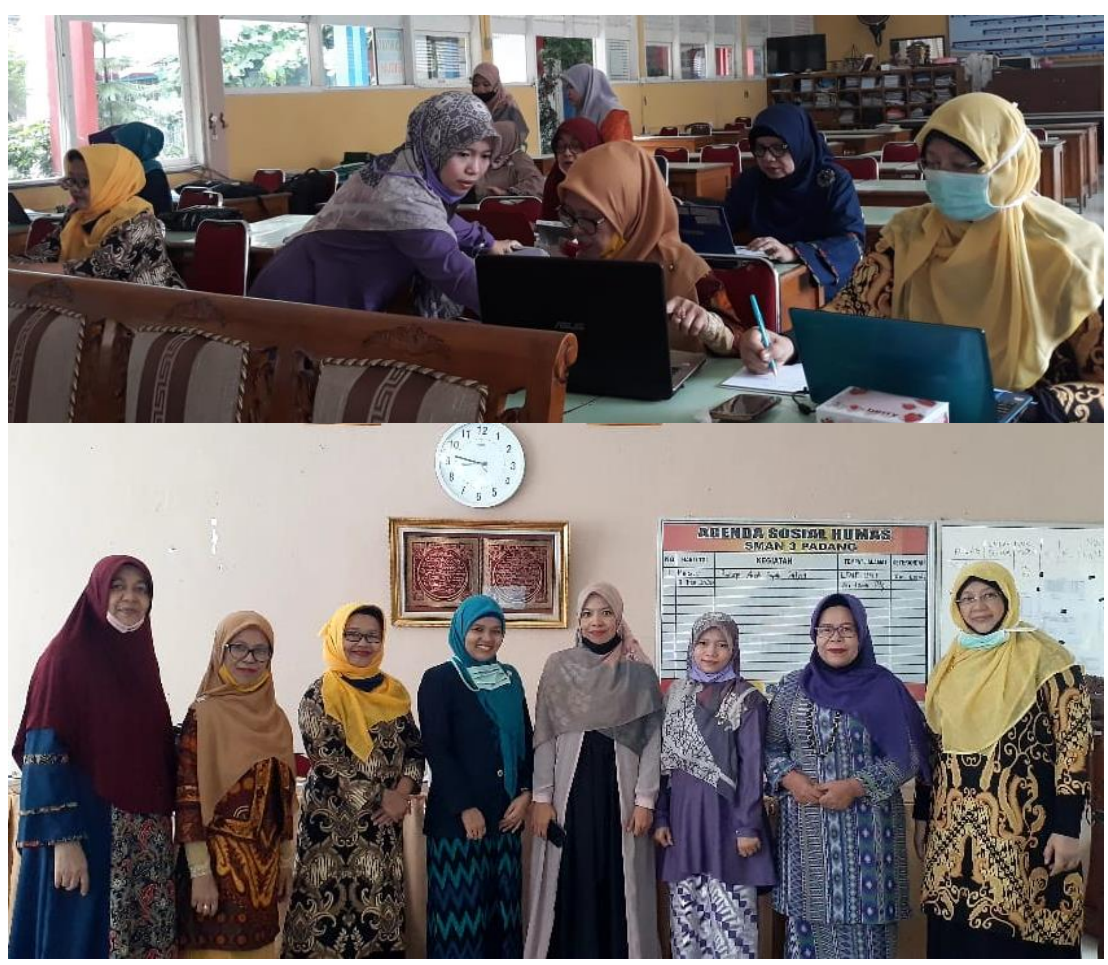

Gambar 3. Kegiatan Pelatihan di SMA Negeri 3 Padang

Berdasarkan hasil wawancara dengan beberapa orang guru yang terlibat pelatihan menggunakan aplikasi Kahoot ini, menyatakan bahwa aplikasi ini sangat cocok untuk para peserta didik. Pada awal pembelajaran daring, materi hanya diberikan melalui Microsoft Word kemudian siswa membaca, sehingga lama-lama siswa merasa bosan. Ketika guru menyuguhkan pembelajaran daring melalui video, siswa sangat antusias dalam mengikuti pembelajaran. Apalagi bila mengerjakan latihan soal berupa kuis melalui aplikasi Kahoot, siswa sangat antusias karena mereka bisa melihat langsung jawaban yang benar dan juga mereka juga dapat melihat langsung skor atau hasil dari pekerjaan mereka. Zoom Meeting hanya sesekali dilaksanakan karena mengingat tidak semua siswa dapat mengaksesnya terlebih ada beberapa siswa yang terkendala sinyal dan penggunakan aplikasi Zoom juga dikhawatirkan banyak menyedt kuota data peserta didik. Selama pembelajaran daring dilaksanakan, hal yang paling sulit dicapai dalam indikator keaktifan belajar siswa adalah ikut serta dalam pemecahan masalah pada materi pembelajaran yang sedang di bahas. Tetapi berdasarkan wawancara dari ke empat siswa tersebut, mereka selalu ikut serta dalam pemecahan masalah agar permasalahan dapat terpecahkan secara bersama-sama (Naziah et al., 2020).

Menurut (Sadikin \& Hamidah, 2020) peserta didik merasa lebih nyaman dalam mengemukakan gagasan dan pertanyaan dalam pembelajaran daring. Mengikuti pembelajaran dari rumah membuat mereka tidak merasakan tekanan psikologis dari teman sebaya yang biasa mereka alami ketika mengikuti pembelajaran tatap muka. Hal ini juga didukung oleh (Sofyana \& Rozaq, 2019) yang menyatakan bahwa penerapan pembelajaran online dinilai efektif apabila diterapkan karena pembelajaran tidak dibatasi ruang dan waktu, yang tidak mewajibkan mahasiswa untuk selalu belajar di dalam ruang kelas dengan segala peraturan yang kaku. Meskipun demikian, menurut (Anugrahana, 2020) pembelajaran daring juga memiliki kelemahan yaitu kurang maksimalnya keterlibatan siswa. Keterlibatan siswa yang 


\section{Rangkiang: Lurnal Pengabdian Pada Masyarakat UPSM STKIP PGR/ Sumatera Barat}

ISSN: (2721-2688) Vol. 2 No 2 (Desember 2020): 124 - 130

dimaksud dapat dilihat dari hasil keterlibatan siswa dalam mengikuti pembelajaran daring secara penuh dari awal pembelajaran sampai akhir pembelajaran.

\section{SIMPULAN}

Hal yang dapat disimpulkan dari hasil kegiatan PPM ini adalah Kahoot sebagai media pembelajaran berbasis digital game based learning dapat dioptimalkan untuk meningkatkan motivasi dan kemandirian peserta didik dan dimanfaatkan untuk memudahkan proses evaluasi pembelajaran. Untuk pengembangan disisi keceradasan intelektual peserta didik, konten kahoot dapat dibuat untuk mendorong peserta didik untuk mendalami setiap materi yang diajarkan.Kahoot dapat dimanfaatkan tidak hanya untuk pembelajaran didalam kelas, namun dapat dimanfaatkan sebagai tugas belajar yang dikerjakan diluar kelas.

\section{DAFTAR PUSTAKA}

Anugrahana, A. (2020). Hambatan, Solusi dan Harapan: Pembelajaran Daring Selama Masa Pandemi Covid-19 Oleh Guru Sekolah Dasar. Jurnal Scholaria, 10(3), 282-289.

Dewi, W. A. F. (2020). Dampak COVID-19 terhadap Implementasi Pembelajaran Daring di Sekolah Dasar. Edukatif: Jurnal Ilmu Pendidikan, 2(1), 55-61. https://doi.org/10.31004/edukatif.v2i1.89

Handarini, O. I. (2020). Pembelajaran Daring Sebagai Upaya Study From Home (SFH) Selama Pandemi Covid 19 Oktafia. Jurnal Pendidikan Administrasi Perkantoran (JPAP), 8(3), 496-503. https://doi.org/10.1093/fampra/cmy005

Khusniyah, N. L., \& Hakim, L. (2019). Efektivitas Pembelajaran Berbasis Daring: Sebuah Bukti Pada Pembelajaran Bahasa Inggris. Jurnal Tatsqif, 17(1), 19-33. https://doi.org/10.20414/jtq.v17i1.667

Malyana, A. (2020). Pelaksanaan Pembelajaran Daring dan Luring Dengan Metode Bimbingan Berkelanjutan Pada Guru Sekolah Dasar Di Teluk Betung Utara Bandar Lampung. Jurnal Ilmiah Pendidikan Dasar Indonesia, 2(1), 67-76.

Naziah, S. T., Maula, L. H., \& Sutisnawati, A. (2020). Analisis Keaktifan Belajar Siswa Selama Pembelajaran Daring Pada Masa Covid-19 Di Sekolah Dasar. Jurnal Paedagogy: Jurnal Penelitian Dan Pengembangan Pendidikan, 7(2), 109-120.

Putria, H., Maula, L. H., \& Uswatun, D. A. (2020). Analisis Proses pembelajaran Dalam Jaringan (DARING) Masa Pandemi COVID-19 pada Guru Sekolah Dasar. Jurnal Basicedu, 4(4), 861-872. https://doi.org/10.31004/basicedu.v4i4.460

Rigianti, H. A. (2020). KENDALA PEMBELAJARAN DARING GURU SEKOLAH DASAR DI DI KABUPATEN BANJARNEGARA. Elementary School, 7(2), 297 302.

Rosali, E. S., Pendidikan, J., \& Universitas, G. (2020). Aktifitas Pembelajaran Daring Pada Masa Pandemi Covid -19 Di. Geography Science Education Journal (GEOSEE), 1(1), 21-30.

Sadikin, A., \& Hamidah, A. (2020). Pembelajaran Daring di Tengah Wabah Covid-19. Biodik, 6(2), 109-119. https://doi.org/10.22437/bio.v6i2.9759

Sofyana, L., \& Rozaq, A. (2019). Pembelajaran Daring Kombinasi Berbasis Whatsapp Pada Kelas Karyawan Prodi Teknik Informatika Universitas Pgri Madiun. Jurnal Nasional Pendidikan Teknik Informatika (JANAPATI), 8(1), 81. https://doi.org/10.23887/janapati.v8i1.17204 